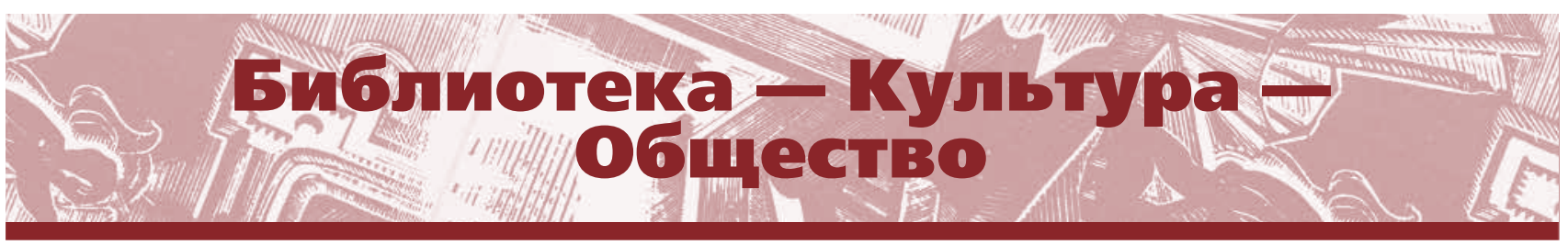

УДК 027.53(470.26)(091)

ББК $78.347 .22(2 \mathrm{Poc} 4$ Каг $)$ г

\title{
С.М. Постникова
}

\section{Информационно-просветительский центр геополитического значения: к 70-летию Калининградской областной научной библиотеки}

В статье представлена история создания Калининградской областной научной библиотеки, организация и развитие библиотечного дела в Калининградской области в период 1946-2016 годов. В 2016 г. исполняется 70 лет со дня образования Калининградской области. В юбилейный для области и библиотеки год в Калининграде - Библиотечной столице России 2016 года - состоится Всероссийский библиотечный конгресс: XXI Ежегодная Конференция Российской библиотечной ассоциации (14-20 мая 2016 года).

Ключевые слова: библиотечное дело, организация библиотечного дела, областная библиотека, история, Всероссийский библиотечный конгресс.

Для цитирования: Постникова С.M. Информационно-просветительский центр геополитического значения: к 70-летию Калининградской областной научной библиотеки // Библиотековедение. 2016. T. 1. № 2. С. $127-135$.

$\mathrm{K}$ енигсбергская область в составе РСФСР была образована Указом Президиума Верховного Совета СССР 7 апреля 1946 года. Одной из важнейших задач Советского государства в послевоенный период стало восстановление и дальнейшее развитие сети библиотек, широкое развертывание библиотечного обслуживания населения. 19 мая 1946 г. в Кенигсберге был создан областной отдел культурно-просветительной работы.

До начала Второй мировой войны Кенигсберг являлся одним из самых богатых библиотечных центров на востоке Германии. Крупнейшее книгохранилище города - Государственная университетская библиотека - насчитывала 700 тыс. томов и около 4700 рукописей. Ее библиотечный фонд складывался на протяжении четырех столетий. В августе 1944 г., когда в результате массированных англо-американских бомбардировок центральная часть Кенигсберга была полностью разрушена, сильно пострадал Королевский замок, в огне пожарищ погибла и часть библиотечного фонда.

Уже в середине апреля 1945 г., вскоре после штурма города, представители Московского государственного университета им. М.В. Ломоно-

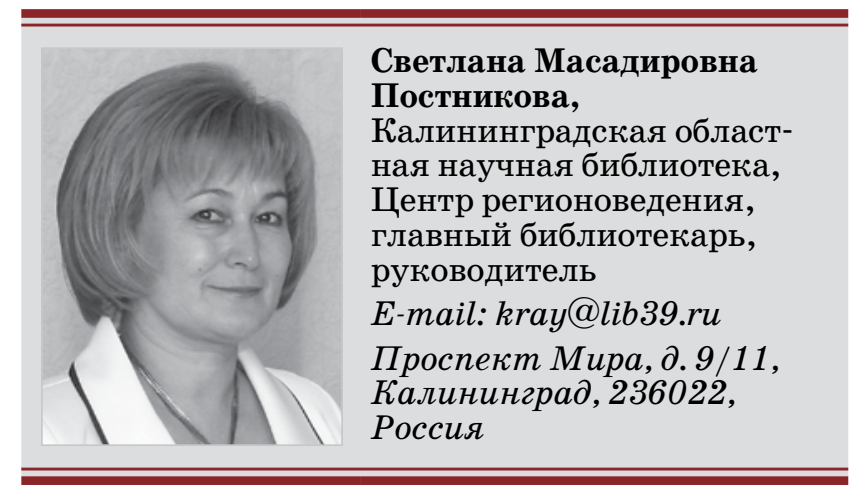

сова во главе с профессором Д.Д. Иваненко обнаружили в руинах Королевского замка каталоги, инвентарные книги музеев. Появились первые сведения о том, что Янтарная комната была вывезена в Кенигсберг. Начали прибывать сотрудники различных организаций Москвы, Ленинграда, Воронежа, Вильнюса и ряда других городов, утративших свои культурные ценности во время войны. Никто не контролировал и не координировал их, хотя они имели минимальные права и полномочия.

28 мая - 13 июня 1945 г. в Кенигсберге начала работу бригада Комитета по делам культурно-просветительных учреждений при СНК РСФСР 


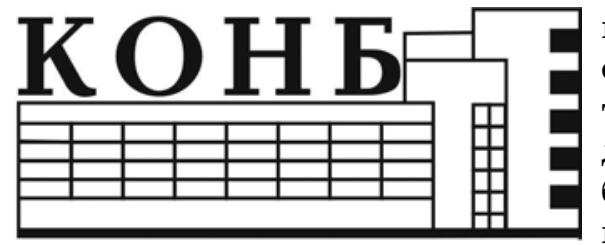

во главе со специ и и с том из Государственной библиотеки им. В.И. Ленина Т.А. Беляевой. Было найдено большое количество культурных ценностей, как местных, так и перемещенных из оккупированных областей бывшего СССР. В собраниях Государственного архива Кенигсберга оказалась ценная коллекция рукописных первопечатных, старопечатных книг, изданий XVII-XVIII вв., инкунабулы, в числе ценных - книги Валленродской библиотеки. Библиотечные коллекции, упакованные в 324 ящика и 24 мешка, а также 60 ящиков с культурными ценностями, с приложением описи предметов, составленной профессором А.Я. Брюсовым, хранились в Государственном архиве Кенигсберга (ныне Калининградская областная научная библиотека). На каждый ящик был нанесен порядковый номер и адрес доставки: Москва, Чистые пруды, 10, Комитет по делам культпросветучреждений при Совнаркоме РСФСР. Но экспонаты по назначению так и не прибыли, их судьба до сих пор неизвестна. Есть косвенные данные о расхищении ценностей [1].

4 июля 1946 г. Указом Президиума Верховного Совета СССР Кенигсбергская область была переименована в Калининградскую, город Кенигсберг - в Калининград. Сразу же в области началась культурно-просветительная работа, было решено открыть городские и районные библиотеки не позднее 15 августа 1946 г., обеспечить их литературой, подобрать помещения, утвердить кадры [2]. Потребность в интенсивном создании культурно-просветительных учреждений объясняется тем, что на период второй половины 1946-1948 гг.

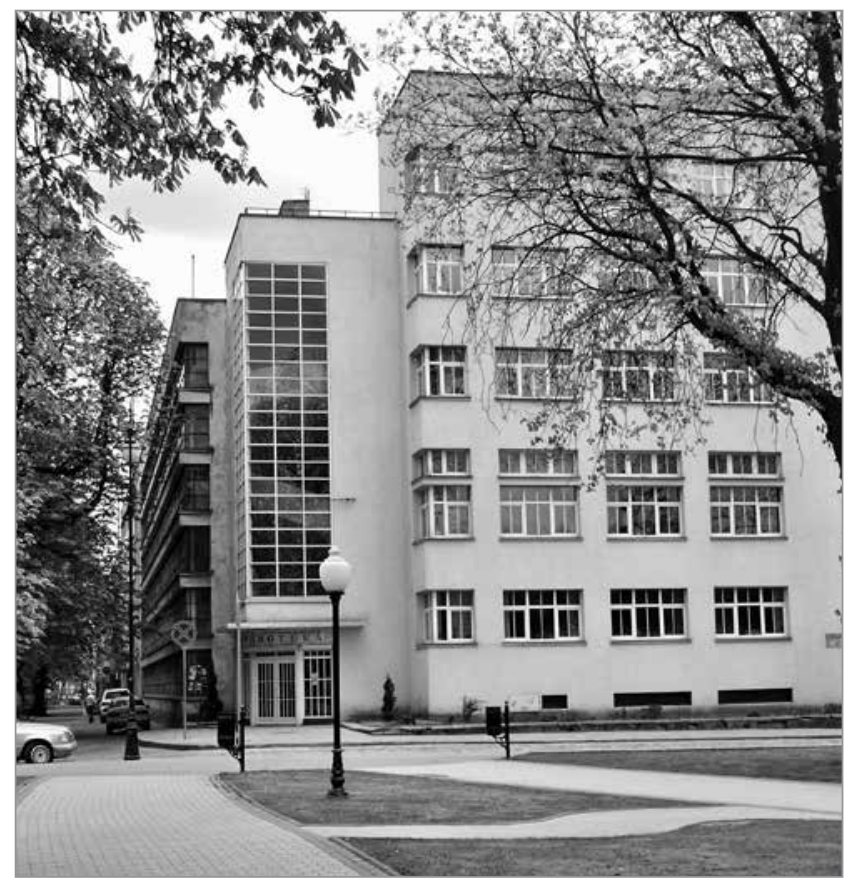

Калининградская областная научная библиотека приходится пик миграций. В 1946 г. в Калининградскую область прибыли 81566 человек, в 1947 г. - 146853 , в 1948 г. - 153642 человека [3].

Калининградская областная научная библиотека была образована в июне 1946 г. (точную дату установить невозможно из-за отсутствия распорядительных документов). Тогда же было подобрано и закреплено за библиотекой здание, где помещался Прусский государственный архив. Архитектор Роберт Либенталь, уроженец Тильзита (ныне г. Советск), спроектировал здание для хранения архива, документы которого находились в северном крыле Королевского замка.

Основой библиотечного фонда послужила литература, присланная из Госфонда и КОГИЗа. Уже к 1 января 1947 г. в областной библиотеке насчитывалось около 35 тыс. томов. В этом же году начали поступать экземпляры из Всесоюзной книжной палаты [4]. Здание, разрушенное военными действиями, требовало большого ремонта. До июня 1947 г. библиотека не могла вести не только какую-либо работу по обслуживанию населения, но и по обработке книг. В зимний период помещение не отапливалось, что, безусловно, снижало темпы и качество работы. Сюда же поступала литература для комплектования городских и районных библиотек, что также требовало мест хранения, сортировки и упаковки книг. Для комплектования районных и городских библиотек иногда поступали партии книг в количестве 20-30 тыс. экз., но при этих условиях обработка книжного фонда проходила очень медленно. Лишь 15 июня 1947 г. областная библиотека временно переехала в помещение городской библиотеки, заняв площадь 92 кв. метра. В течение 20 дней ударной работы удалось открыть небольшой абонемент и читальный зал на 25-30 человек. За 6 месяцев, до конца 1947 г., записалось 3 тыс. читателей, обработано более 30 тыс. книг, написано свыше 13 тыс. каталожных карточек (систематический каталог).

В январе 1947 г. были утверждены структура и штатное расписание областной библиотеки. Из 16 первых библиотекарей высшее специальное образование имели 6 человек, это были «молодые библиотечные кадры, окончившие в 1946 г. Московский государственный библиотечный институт, посланные Комитетом по делам культурно-просветительных учреждений при Совете министров в молодую советскую область...», они приехали «с горячим желанием отдать все свои силы и знания, с умением советского специалиста, не пасующего перед трудностями, делу организации и развития библиотечной сети в новой области» [5].

В 1947-1948 гг. в библиотеке работали 23 человека: в отделе абонемента - 3 , отделе читальных залов - 3 , справочно-библиографическом - 3 , в отделе книгохранения -2 , комплектования и обработки - 4 , административнохозяйственном - 8 человек. 
Библиотекой за 1947 г. было приобретено 40776 экз. книг, число читателей за год составило - 32 тыс. человек, выполнено библиографических справок - 446, книговыдача -56344 экземпляров. Книжный фонд на 1 января 1948 г. насчитывал 70 тыс. книг, в их числе 30 тыс. - необработанного фонда (из них 20 тыс. иностранной литературы на немецком, английском и французском языках).

Несмотря на все трудности библиотека стала оказывать помощь в создании библиотечной системы области. К концу 1947 г. в городах и районах Калининградской области работало 57 библиотек: 1 областная, 7 городских, 4 детских, 14 районных, 31 сельская. Книжный фонд составлял около 250 тыс. книг, в том числе 75 тыс. в областной библиотеке. Кроме того, в сельской местности работало 149 изб-читален, 240 библиотек-передвижек. Лучшими библиотеками в 1947 г. были признаны Черняховская городская, детская г. Калининграда, Полесская районная, Багратионовская районная библиотеки, которые сумели перейти от организационных вопросов к реальной работе, применить все формы и методы библиотечной практики по обслуживанию своих читателей как в деле пропаганды книг, так и в проведении массовых мероприятий с читателями.

С июня 1948 г. немногочисленный коллектив областной библиотеки начал трудиться в восстановленном здании. Был создан Методический совет в составе десяти человек, на котором обсуждались многие злободневные вопросы.

Сотрудники сельских библиотек в основном не имели ни специального, ни общего образования. Остро стоял вопрос об оказании методической помощи и повышении профессионального мастерства сельских библиотекарей. Было проведено 4 семинара в районных библиотеках, 9 практикумов в областной, на которых подготовлено 13 сельских библиотекарей. В течение года третья часть сельских библиотекарей побывали в областной для ознакомления с работой. Были выделены 3 сельские библиотеки как образцово-показательные: Ясновская (Славский район), Мичуринская (Краснознаменский район) и Калиновская (Большаковский район).

Конец 1940 - начало $1950-\mathrm{x}$ гг. отмечены напряженной методической работой со стороны областной библиотеки. Только в 1948 г. проведено 10 крупных совещаний и семинаров, продолжительностью от двух

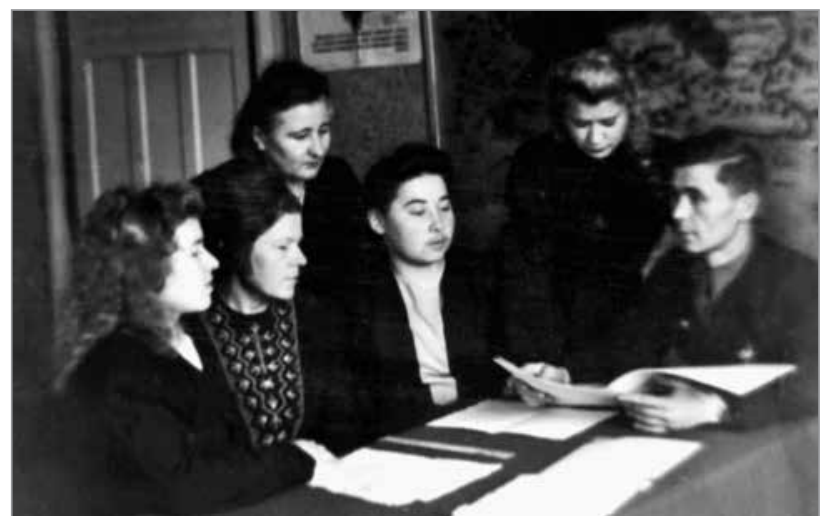

Первые библиотекари - выпускники Московского государственного библиотечного института

до шести дней, 10 практикумов для заведующих сельскими, профсоюзными и школьными библиотеками. Составлено 15 методических разработок и инструктивных писем, осуществлен 31 выезд в организованные библиотеки области. И все это при одном методисте, а весь штат библиотечных работников вместе с директором составлял 16 человек!

Численность населения Калининградской области в 1948 г. составляла - 380,2 тыс. человек. В это время уже работало 142 библиотеки отдела культпросветработы: 1 областная, 17 районных, 10 городских, 5 детских, 109 сельских. Появилась сеть профсоюзных библиотек: 1 областная профсоюзная, 7 библиотек ФЗМК (фабрично- заводских местных комитетов) [6].

К началу 1950-х гг. сеть государственных массовых библиотек была создана, на протяжении последующих десятилетий она претерпевала изменения, но основа была заложена в первые пять лет. Книжный фонд библиотеки формировался на основе поступлений из обменных фондов библиотек Москвы, Ленинграда, других городов CCCP. Среди первых книг - издания XVIII начала XX в., а также небольшая часть книг из библиотек, школ, частных собраний Кенигсберга,

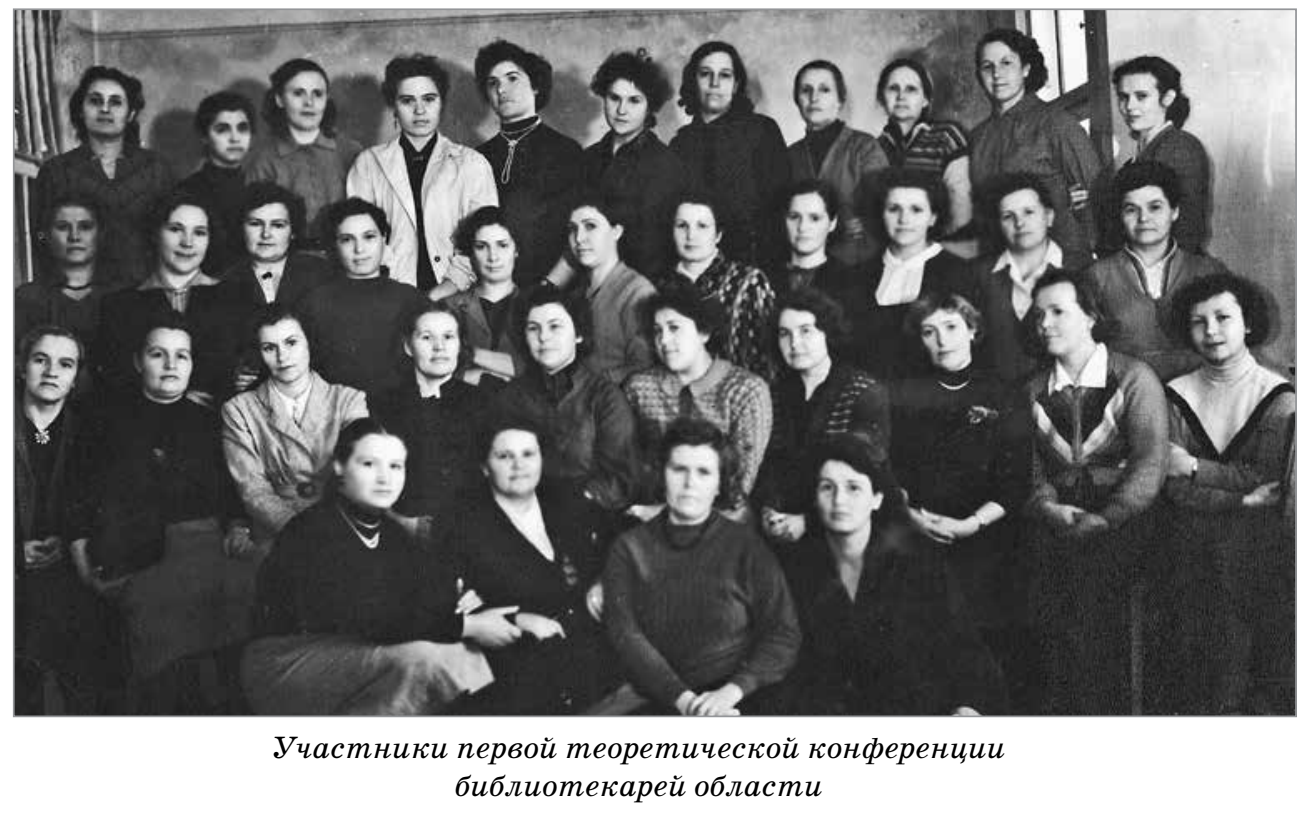


поступивших в период становления библиотеки в первые послевоенные годы.

В первой половине 1960-х гг. в Калининграде создана Центральная научно-техническая библиотека (ЦНТБ) с фондом 142 тыс. ед. хр., которая возглавила сеть технических библиотек области. К середине 1960-х гг. уже около тысячи библиотек различных ведомств обслуживали население области. Они располагали книжным фондом порядка 7 млн экз. печатных изданий. Калининградская область в то время занимала одно из первых мест в Российской Федерации по насыщенности массовыми библиотеками, на каждые 600 человек имелась одна библиотека, на каждого жителя более 10 книг [7].

Долгие годы (с 1962 г.) при библиотеке работал учебно-консультационный пункт Ленинградского государственного института культуры им. Н.К. Крупской по подготовке библиотекарей и культпросветработников высшей квалификации для Калининградской области, республик Прибалтики, Белоруссии.

На 1 января 1970 г. штат областной библиотеки составлял 49 библиотекарей, книжный фонд -570080 экз. изданий. В 1970-е гг. велась большая работа по пропаганде библиотеки и ее фондов на радио, телевидении, страницах газет. Библиотека являлась координатором централизации государственных массовых библиотек путем создания на базе городов и районов области библиотечных объединений с общим штатом, единым фондом, централизованным комплектованием и обработкой литературы. Формировались специализированные отделы по обслуживанию работников сельского хозяйства, нотно-музыкальный сектор, отдел по работе с литературой на иностранных языках. Несколько лет на базе библиотеки работала всесоюзная лаборатория по внедрению новой Библиотечно-библиографической классификации (ББК) в практику работы библиотек страны.

В 1990-е гг. началось внедрение информационных технологий в библиотеки области на основе единого программного обеспечения, методических и технологических разработок областной библиотеки.
С 1994 г. директором библиотеки является заслуженный работник культуры Российской Федерации Н.А. Рузова. Как и первые библиотекари в далеком 1946 г., Нина Александровна, окончив с отличием Московский государственный институт культуры по специальности «библиотекарь-библиограф» в 1974 г., приехала в Калининград. Областная библиотека стала главным делом ее жизни.

Происходящие общественные трансформации активно влияют на библиотеки, меняют не только всю систему библиотечного труда, библиотечные ресурсы, но и самого пользователя. На протяжении последних десяти лет библиотека находилась в стадии инновационного развития, обновления традиционного облика и функций. Это был период внедрения проектного подхода, новых управленческих и информационных технологий, процесса формирования инновационной технологической среды, создания развитой структуры общественных и профессиональных связей на региональном и международном уровнях, повышения профессионализма сотрудников. На основе проведенных исследований создавалась аналитическая база, необходимая для дальнейшего развития и разработки новой стратегии деятельности. Данный этап внес большой вклад в формирование современного образа библиотеки в общественном сознании.

В последние годы традиционные отделы претерпели существенные изменения. Создан отдел обслуживания, объединивший читальный зал, абонемент и сектор регистрации читателей и библиотечной статистики. Стал залоговым абонемент, что позволило практически исключить потерю книг в результате читательской задолженности, создать максимальный уровень сохранности книжного фонда и своевременный возврат наиболее востребованной литературы в библиотеку, расширить перечень книг, выдаваемых на дом, за счет изданий из фондов отделов книгохранения, читального зала, других структурных подразделений. Мобильное информационно-библиотечное обслуживание на территории области осуществляется посредством библиобуса Калининградской областной научной библиотеки, работу которого обеспечивает отдел обслуживания. Муниципаль-

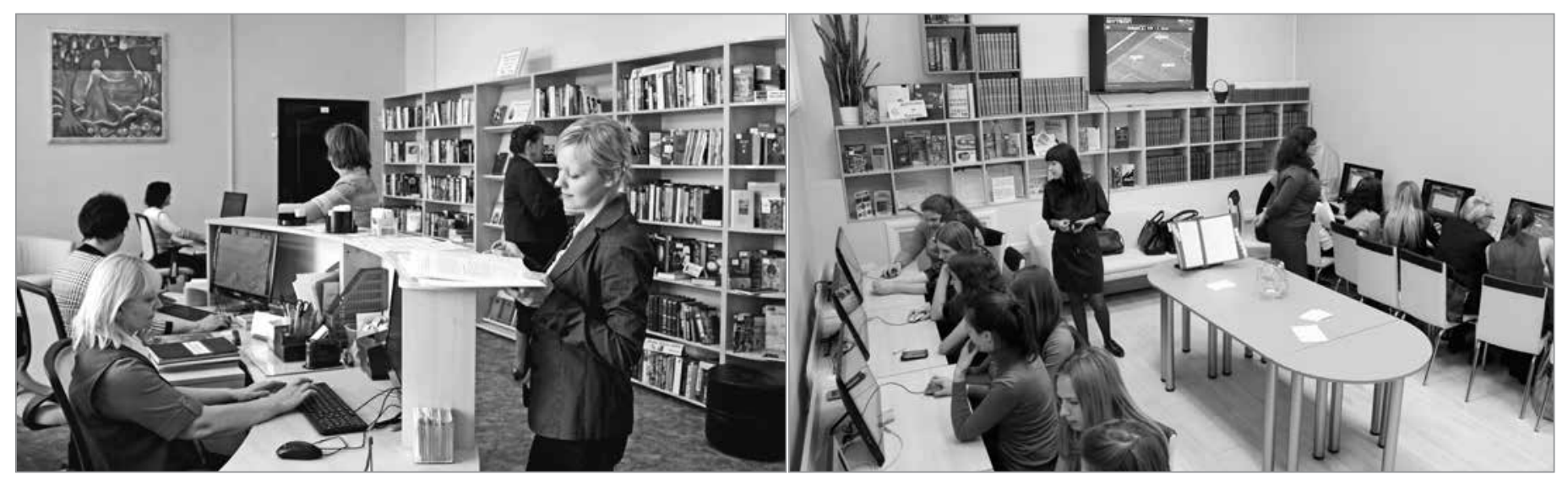


ные библиотеки находятся в девяти районах и 14 городских округах.

Активно развивается информационно-библиографический отдел, выполняющий тысячи сложнейших справок не только на основе традиционных носителей информации, но и с использованием электронных баз данных, ресурсов Интернета. В отделе работает виртуальный читальный зал Российской государственной библиотеки, предоставляющий жителям региона возможность работать с полнотекстовой Электронной библиотекой диссертаций. С 2009 г. внедрена новая форма обслуживания удаленных пользователей - виртуальная справочная служба, развиваются электронная доставка документов и межбиблиотечный абонемент.

Большую работу по правовому просвещению населения проводит Центр правовой информации. К услугам его посетителей - печатные издания нормативно-правовых документов, официальные периодические издания, справочно-правовые системы «Гарант», «Консультант». При отделе работает бесплатная юридическая консультация, проводятся мероприятия по формированию правосознания населения. 27 мая 2014 г. в Калининградской областной научной библиотеке (КОНБ) состоялось открытие Регионального центра доступа к ресурсам Президентской библиотеки им. Б.Н. Ельцина.

В отделе литературы по искусству помимо фонда книг, нот активно формируется медиатека. Центр международного сотрудничества и литературы на иностранных языках принимает участие в международной проектной деятельности библиотеки. Большой популярностью среди жителей Калининграда пользуются клубы по изучению иностранных языков (английского, немецкого, польского, французского, итальянского, арабского).

Отдел инновационной и научно-методической деятельности осуществляет научное обеспечение реализации основных направлений работы, оказывает методическую и практическую помощь библиотекам региона по вопросам библиотечного дела.

Приоритетным направлением деятельности библиотек Калининградской области остается

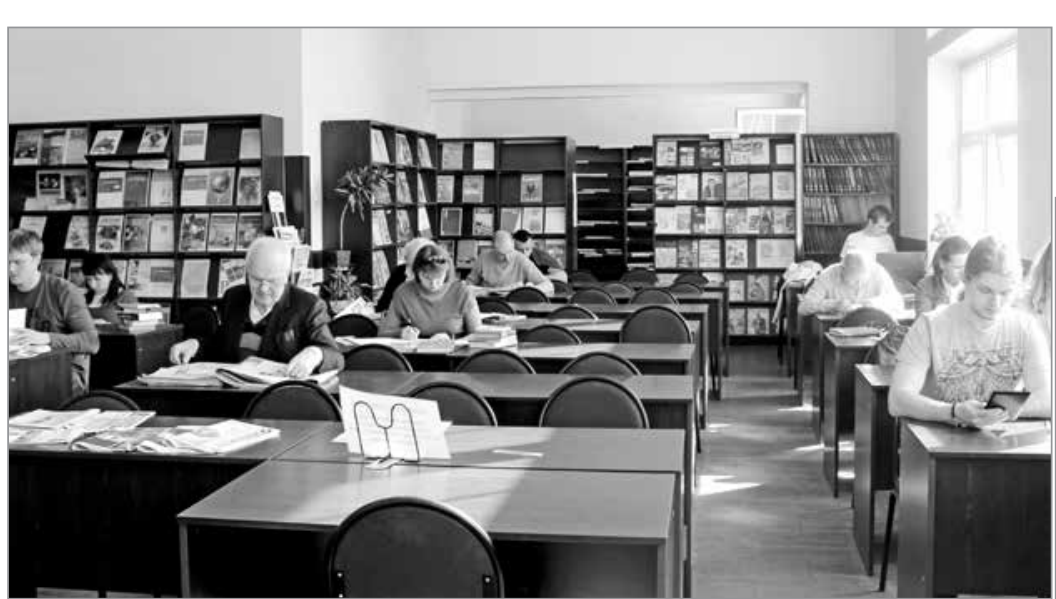

краеведение. С краеведением связана возможность сохранения и модернизации сети публичных библиотек страны в новых экономических условиях, преобразования их в социально-культурные центры, не ограничивающиеся выдачей литературы. Это непосредственно работает на решение таких актуальных государственных задач, как патриотическое воспитание, сохранение памяти нации, социально-культурная адаптация мигрантов и обеспечение толерантности, продвижение брендов территорий, преодоление информационного неравенства.

Одним из динамично развивающихся отделов библиотеки является Центр регионоведения. До конца 1990-х гг. в КОНБ действовал сектор краеведческой библиографии в составе информационно-библиографического отдела. Отдел краеведческой литературы (ОКЛ) был создан в 2000 году. Главная цель организации самостоятельного структурного подразделения - улучшение качества и оперативности обслуживания пользователей за счет объединения в одном отделе печатных и электронных краеведческих ресурсов, справочного аппарата, а также высококвалифицированных сотрудников. В 2012 г. на базе отдела краеведческой литературы создан Центр краеведческой литературы, редких книг, рукописей и специальных коллекций. $\mathrm{K}$ ранее имеющимся фондам краеведческой литературы, архиву местной печати присоединили самостоятельный фонд редких книг. Штат сотрудников отдела редких книг (четыре человека) вошел в новое структурное подразделение - Региональный центр изучения и продвижения чтения.

К этому времени фонд редких книг стал обладателем рукописей, коллекций ценных библиотечных собраний известных писателей, ученых, деятелей культуры, проживавших в Калининграде. Издания XVII-XIX вв. по истории Пруссии, книги кенигсбергских издательств, открытки позволяют знакомиться с образцами иностранной печати, не выезжая за пределы анклава. Сформировался значительный фонд нетрадиционной печати по истории калининградской области: афиши, плакаты, листовки и др.

Многогранная работа Центра краеведения, выполнение большого объема справок, информационных запросов по всем отраслям развития

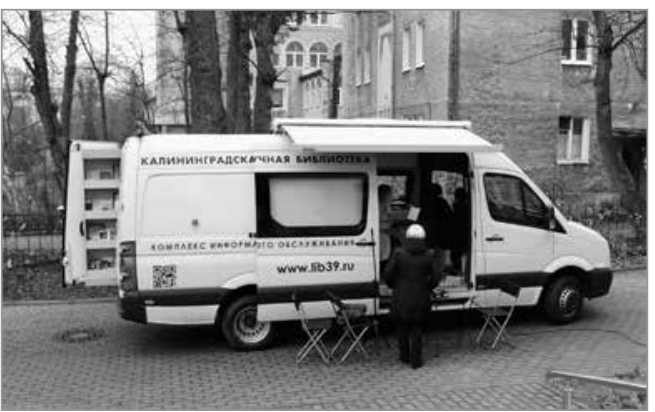


региона, активная издательская деятельность, уникальность истории региона, многонациональный состав населения, геополитическое положение привели к необходимости расширить полномочия Центра. Усилия по созданию регионального информационно-аналитического центра по вопросам краеведения и развития отраслей народного хозяйства области нашли свое претворение в структурных преобразованиях: 1 июля 2015 г. на базе Центра краеведения, редких книг, рукописей и специальных коллекций был создан Центр регионоведения. В структуру Центра вошли следующие группы: обслуживания и массовой работы; регионоведческих фондов и коллекций; регионоведческой библиографии; фондов редких книг, рукописей и специальных коллекций; межрегионального и международного сотрудничества; маркетинга и рекламы; Региональный центр чтения. Сегодня в штате отдела - 18 сотрудников (библиотекари, историк, филологи, маркетолог, специалист по сервису и туризму, переводчики, философы).

В 2016 г. исполняется 10 лет Историко-родословному обществу (ИРО). За это время было издано семь выпусков «Калининградского родословного вестника». Архив электронных документов по генеалогии калининградских семей сохраняется в КОНБ. Исследовательская работа членов ИРО, научная, просветительская, издательская деятельность библиотеки способствует сохранению частного документального наследия. В 2014 г. на Всероссийском конкурсе научных работ по библиотековедению, библиографии и книговедению Калининградский родословный вестник (выпуски 4-5) признан лучшей научной работой региональных библиотек [8, 9].

Краеведческой деятельностью занимаются профессионалы и общественные объединения, частные лица и учреждения. Многие годы КОНБ активно сотрудничает с Областным историко-художественным музеем, городским муниципальным музеем «Фридландские ворота», Музеем янтаря, Калининградским клубом краеведов, областным детско-юношеским центром краеведения, экологии и туризма, Балтийским федеральным университетом им. И. Канта, среди партнеров - колледжи, школы и другие образовательные учреждения. В числе совместных проектов - участие в создании корпоративного краеведческого каталога, семинары-практикумы «Дорогами Янтарного края» с пешеходными экскурсиями. Ежегодно публикуются библиографии изданий по истории края на страницах «Балтийского альманаха», библиотекари участвуют в областных краеведческих конференциях, входят в состав экспертных комиссий в конкурсах по краеведению.

Сотрудники библиотеки ведут большую просветительскую работу: организуют выставки, литературно-музыкальные вечера, семинары, презентации книг, встречи с интересными людьми, лекции по психологии, философии, истории искусства и литературы, экскурсии по литературным местам Калининграда. Библиотека является координатором ежегодных Дней литературы в Калининградской области - крупнейшего культурного форума региона. Ежегодно в рамках этого проекта проходят мероприятия, которые способны удовлетворить самые разнообразные литературные вкусы: литературные акции, творческие встречи с писателями и издателями, выставки и презентации книг, беседы, конференции, литературные вечера и вечера памяти, а также концерты-спектакли по произведениям русской литературы.

История Дней литературы началась 19 октября 2001 г. с празднования Дня Лицея. В этот день состоялась встреча у памятника А.С. Пушкина, которая впоследствии стала традиционной. По итогам первых Дней литературы организаторы проекта - управления культуры и образования Калининградской области, администрации муниципальных образований и писательские организации региона - приняли решение о том, что эти литературные мероприятия должны стать традицией в культурной жизни края. Теперь каждый год в середине октября все поклонники литературы Калининградской области могут окунуться в атмосферу грандиозного культурного праздника. За все время проведения Дней литературы сложилась определенная устойчивая структура мероприятий. Программа праздника традиционно включает в себя: День Царскосельского лицея, Лермонтовский день, фестиваль «Гумилевская осень», литературные встречи в музее Кристионаса Донелайтиса и творческие вечера калининградских авторов.

Снижение интереса к чтению, которое наблюдается в последние годы как в России, так и в других странах мира, вызывает тревогу не только у специалистов книжного и библиотечного дела, но и у широкой общественности. Министерство культуры Калининградской области предпринимает усилия для того, чтобы не только расширить ряды сторонников «читающего образа жизни», но и поддержать тех, кто книги пишет и выпускает. Издательский проект Министерства культуры при поддержке Правительства Калининградской области начался в 2006 году. Его основные задачи: увеличить число читателей, пополнить фонды библиотек новыми интересными книгами и поддержать местных писателей, поэтов, в том числе начинающих свой путь в литературе. В рамках проекта издаются книги местных авторов для библиотек области на средства областного бюджета. Каждый год объявляется творческий конкурс на издание книг - это социально-значимая литература, историческая (серия «Роман по истории края»), книги известных писателей и начинающих авторов (серии «Литературное наследие» и «Литературный дебют»), поэтические сборники (серия «Калининградская поэзия»), книги для детей и подростков. 
Особый раздел «Библиотеки Правительства Калининградской области» составили книги серии «ЛИК» (Личность. История. Край), содержащие очерки о жизни и деятельности знаменитых людей, оставивших след в истории края. За десять лет своей жизни проект способствовал пополнению фондов государственных и муниципальных библиотек региона 120 наименованиями новых книг тиражом более 70 тыс. экземпляров. В ходе ежегодного отбора экспертным советом было поддержано более ста калининградских авторов.

В 2007 г. был реализован литературный интернет-фестиваль «Еврочтение-2007». Суть этого конкурса заключалась в том, что молодые люди из России, Польши и Литвы на созданной интернет-платформе размещали эссе в двух категориях: посвященные творчеству отечественного или зарубежного писателя. Профессиональное жюри и пользователи Интернета определили лауреатов конкурса (по восемь человек из каждой страны). Интеллектуальный проект «Еврочтение-2007» показал, что молодое поколение - читающее, и хорошие книги даже в эру новых технологий найдут свое место в сердце читателя.

Областная библиотека - участник многих международных проектов. Брендом калининградского библиотечного сообщества стала «Международная библиотечная философская школа» (МБФШ). Проект реализуется с 2004 г. Министерством культуры Российской Федерации, Академией переподготовки работников искусства, культуры и туризма, Министерством культуры Калининградской области, КОНБ и Черняховской центральной библиотечной системой. Главная цель проекта - способствовать разработке философских основ развития библиотек в электронную эпоху как базового звена системы социально-информационных коммуникаций и транслировать полученное знание в широкие круги профессионального сообщества.

Самыми близкими кругами профессионального сообщества в данном случае являются библиотекари Калининградской области. Они имеют возможность принимать участие в работе МБФШ, слушать ведущих теоретиков и практиков библиотечного дела, философов, культурологов, политологов, социологов.

Все это расширяет общий и профессиональный кругозор, обогащает новыми знаниями. Калининградская область не случайно выбрана для проведения МБФШ: на этой земле, в Кенигсберге, родился и творил И. Кант (1724-1804), один из величайших философов, наследие которого изучает и развивает кафедра философии Балтийского федерального университета им. И. Канта в Калининграде. Регион Балтия - это традиционное место экономических, культурных и научных связей народов Европы и всего мира, что создает особые благоприятные условия для работы МБФШ и развития международных научных контактов в рамках ее сессий.

Еще одним знаковым событием в развитии библиотечного дела в Калининградской области стало создание в сентябре 2012 г. Калининградской библиотечной ассоциации. Обеспокоенность библиотечного сообщества состоянием библиотечного дела в регионе привела к осознанию необходимости объединить свои усилия в профессиональной и общественной сферах, «способствовать тому, чтобы наши библиотеки отвечали тем требованиям, которые предъявляет сегодня общество: открытость, доступность, новое содержание, на-

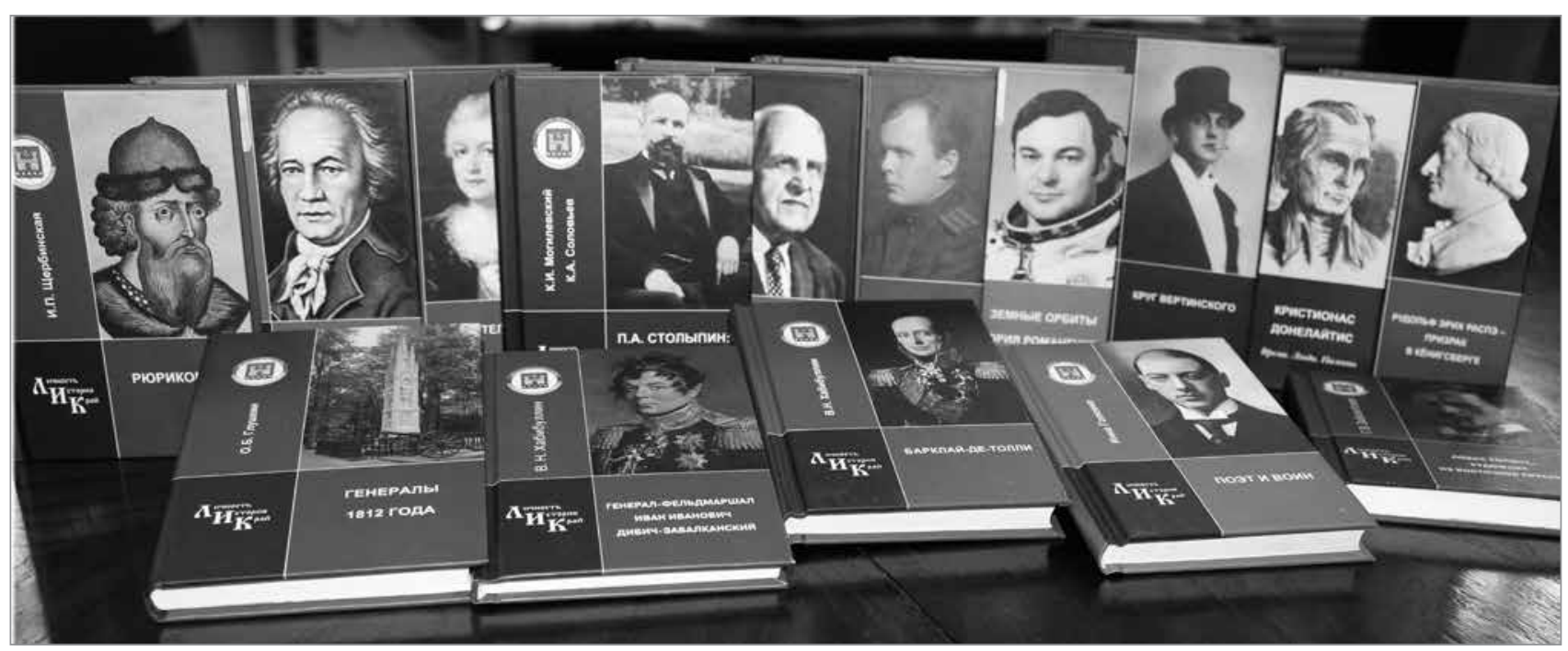

Книги серии «ЛИК» 
правленное на развитие личности, способствующее продвижению чтения, расцвету общества» [10].

Заметным явлением стал XIII Форум публичных библиотек России «Библиокараван-2014», в работе которого приняли участие библиотечные специалисты четырех государств: России, Польши, Литвы и Беларуси. Больше всего слушателей собрало заседание «Проектная деятельность публичных библиотек: эволюция форм и перспектив», что говорит об актуальности проблемы социокультурного проектирования. Коллеги из публичных библиотек Сургута, Омска, Домодедова, Кемерова, Мурманска, Выборга, Клайпеды поделились своим опытом работы, рассказали о реализованных проектах различной содержательной направленности. Форум способствовал разработке новых международных проектов и подписанию соглашений о сотрудничестве между Районной библиотекой Гарждай (Литва) и Зеленоградской городской библиотекой им. Ю.Н. Куранова (Калининградская область).

История любой библиотеки примечательна тем, что в ней тесно переплетаются история страны и судьбы тех, кто в ней работал. Не исключением стала и Калининградская областная научная библиотека. Развиваясь вместе с поколениями своих читателей, она прошла путь от идеологического учреждения до информационно-просветительского центра, успешно реализующего свои собственные научные и творческие проекты.

2016 г. для Калининградской области юбилейный - 70-летие со дня образования. Ровесницей области является и Калининградская областная научная библиотека. Главное и крупнейшее событие года в библиотечной сфере - Всероссийский библиотечный конгресс: XXI Ежегодная конференция Российской библиотечной ассоциации, которая пройдет 14-20 мая 2016 г. в Калининграде Библиотечной столице России 2016 года.

Город, которому присуждается этот статус, получает серьезный стимул к развитию библиотечного дела. Местные библиотеки становятся объектом особого внимания, а со стороны профессиональных библиотечных кругов возрастает интерес к библиотечному опыту данной территории. Калининградская область - один из значимых культурных центров России, так как здесь реализуется огромное количество творческих проектов. «Права носить статус "Библиотечной столицы России” удостаиваются те регионы, в которых заметна активная деятельность в области литературы и библиотечного дела. Нам, конечно, предстоит еще много работы. Но мы не стоим на месте и используем для развития литературы региона все направления: тесно сотрудничаем с писательскими организациями и книжными магазинами, придумываем новые проекты для наших библиотек, проводим дни литературы и многое другое», — отмечает министр культуры Калининградской области С.А. Кондратьева [11].
В рамках этого значимого события Калининградская библиотечная ассоциация объявила Калининград Столицей читателей в 2016 году! Центральным объектом всех планируемых мероприятий становятся читатели, для которых библиотеки предлагают новые информационные продукты и совершенствуют формы общения. Именно для читателей библиотечные специалисты развивают профессионализм, реализуют новые творческие проекты, внедряют инновации в свою работу.

\section{Список источников}

1. Овсянов А.П. Их благодарила «Сикстинская мадонна» : малоизвестные страницы Великой Отечественной войны и ее последствий. Калининград : Аксиос, 2012. С. $98-101$.

2. Рузова Н.А. История становления и развития библиотечного дела Калининградской области : доклад к 50-летию Калининградской областной универсальной научной библиотеки : рукопись // Архив Центра регионоведения КОНБ. Калининград, 1996. С. 2.

3. Костяшов Ю.В. Обратничество в процессе заселения Калининградской области в послевоенные годы // Балтийский регион в истории России и Европы / под ред. В.И. Гальцова. Калининград : Изд-во РГУ им. И. Канта, 2005. С. 212.

4. Бурла И.А. Книги - народу // Продолжение подвига. Калининград : Калининградское книжное изд-во, 1967. С. 211.

5. Информационный годовой отчет Калининградской областной библиотеки за период 1947 г. // Государственный архив Калининградской области. Ф. 289. Оп. 7. Д. 16. Л. 34-35.

6. Отчет Калининградской областной библиотеки за 1948 год // Архив Центра регионоведения КОНБ.

7. Рузова Н.А. Да не иссякнет источник, питающий просвещение // Библиотека. 1999. № 1. С. 27.

8. Калининградский родословный вестник. Вып. 4 / Калинингр. обл. науч. б-ка. Центр краевед., редких книг, рукописей и спец. коллекций, Зап. (Калинингр.) отд-ние Историко-родослов. о-ва в Москве ; ред.-сост. С.М. Постникова. Калининград : Янтар. летопись, 2012. $144 \mathrm{c.}$

9. Калининградский родословный вестник. Вып. 5 / Калинингр. обл. науч. б-ка. Центр краевед., редких книг, рукописей и спец. коллекций, Зап. (Калинингр.) отд-ние Историко-родослов. о-ва в Москве ; ред.-сост. С.М. Постникова. Калининград : Янтар. летопись, 2013. 128 с.

10. Рузова Н.А. Зачем калининградским библиотекарям нужна ассоциация? // Библиотечное дело. 2014. № 7. C. 39 .

11. Калининград станет «Библиотечной столицей России» в 2016 году [Электронный ресурс] // Правительство Калининградской области : Официальный портал. URL: http://gov39.ru/news/101/83112/ (дата обращения: 31.03.2016).

Иллюстративный латериал предоставлен авторол статьи 


\section{S.M. Postnikova}

\section{Information and Educational Center of Geopolitical Value: to the 70th Anniversary of the Kaliningrad Regional Scientific Library}

There is presented the history of creation of the Kaliningrad Regional Scientific Library (KRSL), organization and development of librarianship in the Kaliningrad Region in 1946-2016. In 2016 Kaliningrad region celebrates its 70th anniversary. In this jubilee year for the Region and for the Library there will be held in Kaliningrad - the Library Capital of Russia in 2016 - the All-Russian Library Congress: the 21st Annual Conference of the Russian Library Association (14-20 May, 2016).

Key words: Librarianship, Organization of Librarianship, Regional Library, History, the All-Russian Library Congress.

Citation: Postnikova S.M. Information and Educational Center of Geopolitical Value: to the 70th Anniversary of the Kaliningrad Regional Scientific Library, Bibliotekovedenie [Library and Information Science], 2016, vol. 1, no. 2, pp. 127-135.

\author{
About author \\ Svetlana Masadirovna Postnikova, \\ The Kaliningrad Regional Scientific Library, \\ Center for Regional Studies, \\ Chief Librarian, Head \\ E-mail:kray@lib39.ru \\ 9/11, Prospekt Mira, \\ Kaliningrad, 236022, Russia
}

\section{References}

1. Ovsyanov A.P. Ikh blagodarila "Sikstinskaya madonna": maloizvestnye stranitsy Velikoi Otechestvennoi voiny i ee posledstvii. Kaliningrad, Aksios Publ., 2012, pp. 98-101.

2. Ruzova N.A. Istoriya stanovleniya i razvitiya bibliotechnogo dela Kaliningradskoi oblasti: doklad k 50-letiyu Kaliningradskoi oblastnoi universal'noi nauchnoi biblioteki (manuscript), Center for Regional Studies of the Kaliningrad Regional Scientific Library Archive. Kaliningrad, 1996, p. 2.

3. Kostyashov Yu.V. Obratnichestvo v protsesse zaseleniya Kaliningradskoi oblasti v poslevoennye gody, Baltiiskii region v istorii Rossii i Evropy. Kaliningrad, I. Kant RSU Publ., 2005, p. 212.

4. Burma I.A. Knigi - narodu, Prodolzhenie podviga. Kaliningrad, Kaliningrad book Publ., 1967, p. 211.

5. Informatsionnyi godovoi otchet Kaliningradskoi oblastnoi biblioteki za period 1947 g., State Archive of the Kaliningrad region, coll. 289, aids 7 , fol. 16 , pp. $34-35$.
6. Otchet Kaliningradskoi oblastnoi biblioteki za 1948 god, Center for Regional Studies of the Kaliningrad Regional Scientific Library Archive.

7. Ruzova N.A. Da ne issyaknet istochnik, pitayushchii prosveshchenie, Biblioteka [Library], 1999, no. 1, p. 27.

8. Postnikova S.M. (ed.) Kaliningradskii rodoslovnyi vestnik, issue 4. Kaliningrad, Yantar. letopis' Publ., 2012, $144 \mathrm{p}$.

9. Postnikova S.M. (ed.) Kaliningradskii rodoslovnyi vestnik, issue 5. Kaliningrad, Yantar. letopis' Publ., 2013, $128 \mathrm{p}$.

10. Ruzova N.A. Zachem kaliningradskim bibliotekaryam nuzhna assotsiatsiya?, Bibliotechnoe delo [Librarianship], 2014, no. 7, p. 39.

11. Kaliningrad stanet «Bibliotechnoi stolitsei Rossii» v 2016 godu, Pravitel'stvo Kaliningradskoi oblasti [Official website of the Kaliningrad Region Gavernment]. Available at: http://gov39.ru/news/101/83112/ (accessed 31.03.2016). 